\title{
Analysis of Unequal Distribution of Population Income in Indonesia
}

\author{
Nano PRAWOTO' ${ }^{1}$, Richa Dwi CAHYANI ${ }^{2}$
}

Received: April 09, 2020 Revised: May 03, 2020 Accepted: June 07, 2020

\begin{abstract}
Income inequality is a problem that is not only faced by developing countries such as Indonesia, but also developed countries. The difference lies in the proportion of an inequality that occurs and the solution to the level of difficulty experienced. Thus, this study aims to empirically analyze the unequal distribution of population income in Java island, Indonesia, by including the human development index, open unemployment rate, foreign investment, and the degree of fiscal decentralization. The research model used in this study was multiple linear regression to analyze the panel data with a fixed-effect model approach. The results of the study showed that human development index, open unemployment rate, and the degree of fiscal decentralization had a positive and significant effect on income inequality in Java island. Meanwhile, foreign investment had a negative and insignificant effect on income inequality in Java. It is because the value of the investment is more invested in the capital-intensive sector. The government is expected to be more selective in accepting foreign investments that enter the country, especially in Java, and it should be labor-intensive investments. In addition, the government has to equalize locations for foreign investment without reducing good cooperation with these foreign investors.
\end{abstract}

Keywords: Human Development Index, Foreign Investment, Income Distribution, Indonesia

JEL Classification Code: F21, O15, R42

\section{Introduction}

Income inequality is a problem that is not only faced by developing countries, but also developed countries (Banister, Bloom, \& Rosenberg, 2012; Li, Wang, Xu, \& Yuan, 2020). The difference lies in the proportion of an inequality that occurs and the solution to the level of difficulty experienced (Molero-Simarro, 2017; Shi \& Chuliang, 2011; Xie \& Zhou, 2014). The state of income distribution in several countries is divided into two categories, namely, the distribution of relative income and the distribution of absolute income.

${ }^{1}$ First Author and Corresponding Author. Lecturer, Business and Economic Faculty, Universitas Muhamadiyah Yogyakarta, Indonesia [Postal Address: Jl. Brawijaya, Geblagan, Tamantirto, Kec. Kasihan, Bantul, Daerah Istimewa Yogyakarta 55183, Indonesia]

Email: nanopra@umy.ac.id

${ }^{2}$ Business and Economic Faculty, Universitas Muhammadiyah Yogyakarta, Indonesia, Email: richadwicahyani@gmail.com

(c) Copyright: The Author(s)

This is an Open Access article distributed under the terms of the Creative Commons Attribution Non-Commercial License (http://Creativecommons.org/licenses/by-nc/4.0/) which permits unrestricted noncommercial use, distribution, and reproduction in any medium, provided the original work is properly cited.
The relative income distribution is the ratio of the amount of income received by various income earners, which are divided into three groups, namely, 40 percent of the population receiving the lowest income, 40 percent of the middleincome population, and 20 percent of the highest-income population. Whereas, the absolute income distribution is the percentage of the population whose income reaches a certain level or below the level (Sukirno, 2006).

The indicator used to determine income inequality is the Gini coefficient or the Gini index, which ranges from zero to one. The Gini index of zero indicates perfect equality, where everyone has almost the same income. Meanwhile, the Gini index of one indicates perfect inequality (Hudiyanto, 2017). Moreover, Java island is a central area of activity in Indonesia, both for economic and government centers. This condition should be able to reduce inequality in the distribution of people's income compared to other islands, such as Sumatra, Kalimantan, Sulawesi, Papua, Bali, and Nusa Tenggara. However, this condition has not been able to enable the island of Java to suppress inequality compared to other islands, which can be seen from the measurement number of income inequality. Table 1 performs the data on the development of the inter-island Gini index in Indonesia: 
Table 1. The Average Inter-Island Gini Index Values in Indonesia in 2012-2018

\begin{tabular}{|c|c|c|c|c|c|c|}
\hline Year & Java & Sumatera & Kalimantan & Sulawesi & Bali & Papua \\
\hline 2012 & 0.404 & 0.367 & 0.363 & 0.397 & 0.369 & 0.385 \\
\hline 2013 & 0.394 & 0.352 & 0.366 & 0.404 & 0.377 & 0.381 \\
\hline 2014 & 0.414 & 0.35 & 0.363 & 0.399 & 0.396 & 0.379 \\
\hline 2015 & 0.406 & 0.336 & 0.318 & 0.38 & 0.369 & 0.361 \\
\hline 2016 & 0.395 & 0.337 & 0.332 & 0.382 & 0.367 & 0.363 \\
\hline 2017 & 0.4 & 0.331 & 0.329 & 0.386 & 0.372 & 0.359 \\
\hline 2018 & 0.4 & 0.325 & 0.331 & 0.375 & 0.371 & 0.362 \\
\hline
\end{tabular}

Source: Statistics Indonesia, 2012-2018

The Human Development Index was introduced by the United Nations Development Program (UNDP) in 1990 and published gradually in the annual Human Development Report (HDR). The three basic dimensions of the Human Development Index are the Health Index, the Education Index, and the Expenditure Index.

Human resources are the most critical aspects in economic growth (Chulanova, Satybaldin, \& Koshanov, 2019; Chulanova \& Ussenova, 2015; Haerani, Hakim, \& Putra, 2020; Han \& Lee, 2020; Le, Duy, \& Ngoc, 2019; Park, 2020; Srivastava \& Talwar, 2020; Udin, 2020). Besides, people are one of the nation's real assets; thus, the ultimate goal of development must focus on people (Bethencourt \& Perera-Tallo, 2020; Xu \& Li, 2020). The economic performance will affect human development both directly and indirectly in terms of income levels, as well as the distribution of income in society. Human Development in the field of education and health will affect the ability to absorb and manage the sources of economic growth. It can also strengthen the effect of the level of education and good health. According to Prawoto (2019), unemployment is another problem in the economy besides the problem of low economic growth, high inflation rates, imbalance of payments, and others. It has been a long-time problem encountered by almost all countries (Adelowokan, Maku, Babasanya, \& Adesoye, 2019; Crucianu \& Alexandra, 2019; Pasara \& Garidzirai, 2020; Pratomo \& Setyadharma, 2020; Rainsford, Maloney, \& Popa, 2019; Semra, 2020; H. D. Shukla, 2020). Countries that have an unemployment rate below $4 \%$ are categorized to be in a state of full employment.

Therefore, open unemployment is unemployment that has not been accommodated in the economic sector. It is part of the workforce, both who are not currently employed and who are looking for a job (who has never worked, or who has ever worked temporarily), who are preparing a business, who are not looking for work as they feel that they are unable to get work, and those who have a job, but have not started it yet. The indicator in open unemployment can be identified by comparing between the total number of 15 -year old people and above who are looking for work and the total population in the workforce. Meanwhile, job loss or unemployment is a problem that directly affects people and becomes an economic issue as well as a measure of the level of social welfare that is arduous to deal with in human life. To most people, job loss will reduce current living standards, and concerns for the future that will decrease people's income (Mankiw, 2018). Further, investment is basically economic development activities that can be carried out by both private and public parties, which aim to increase economic growth and, in the long run, can improve the people's living standards (Afonso \& Aubyn, 2019; Firmansyah \& Nasih, 2019; Gilbert \& François, 2020; Gu \& Prah, 2020; Hanif, Faraz Raza, Gago-de-Santos, \& Abbas, 2019; Pradhan, Arvin, \& Hall, 2019; O. P. Shukla, 2020; Udemba, Magazzino, \& Bekun, 2020).

Fiscal decentralization is a process of budget distribution from the level of central government or higher government to lower government (Canavire-Bacarreza, MartinezVazquez, \& Yedgenov, 2020; Faridi, Mehmood, Azam, \& Taqi, 2019; Yang, 2016), which aims to support the functions or tasks of the government in the public service system in accordance with the authorities and responsibilities of bureaucracy in Indonesia (Fahmi, 2018). Income inequality cannot be separated from economic policies, especially fiscal policies, such as taxation and subsidies, monetary or banking policies, and other policies (Tambunan, 2018). The financial relationship mechanism delegated to the regional government is expected to develop the regional economy since, basically, only the region knows the needs of an area.

Java, as the center of the economy and also the center of government, does not guarantee that the economic welfare of the people on the island is evenly distributed among one another. Based on the above phenomenon regarding the problem of inequality of income distribution, this study aims to analyze the influence of the Human Development Index (IPM), Open Unemployment Rate (TPT), Foreign 
Investment (PMA), and the Degree of Fiscal Decentralization on the inequality of income distribution in Java in the 20122018 period.

\section{Research Methods}

The object of research in this study covered six provinces in Java, consisting of DKI Jakarta, West Java, Central Java, DIY, East Java, and Banten. The data in this study were qualitative, namely, numerical data obtained from the Central Statistics Agency and the Investment Coordinating Board. The secondary data type used in the study was in the form of panel data. It was a combination of time-series data from 2012-2018 (seven years) and cross-section data from six provinces in the Java island. The variables used included the Gini index variable as the dependent variable, while the independent variables included the Human Development Index variable, Open Unemployment Rate, Foreign Investment, and the Degree of Fiscal Decentralization. The equation model in this study is as follows:

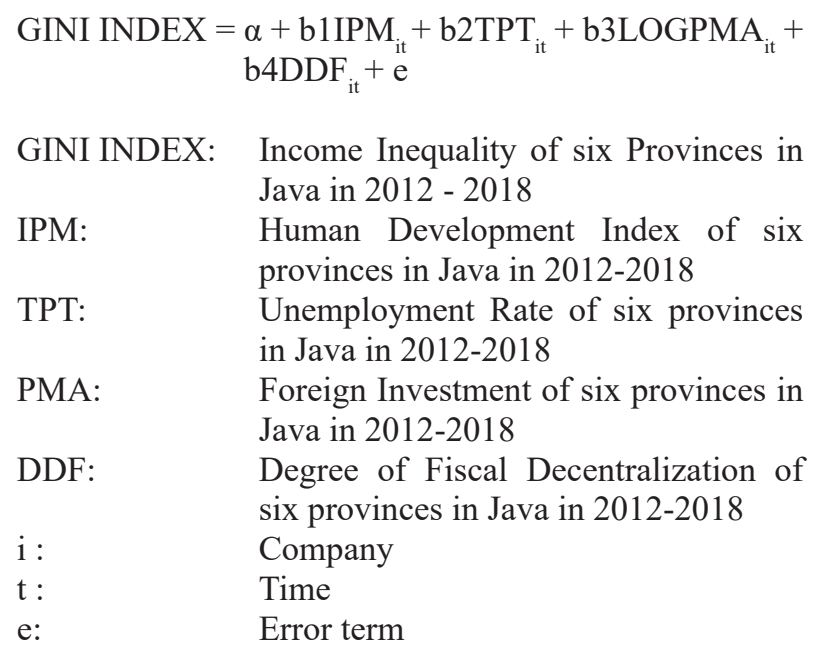

According to Basuki (2017), there are three methods or approaches taken to estimate the regression model with panel data, namely the Common Effect Method, Fixed Effect Method, and Random Effect Method. In determining the most appropriate technique or model for estimating panel data regression, the researcher must select the estimation technique by conducting three tests. Firstly, the Chow Test is the most appropriate test to be utilized in panel data, which is applied to selecting between the Common Effect or Fixed Effect methods. Second, the Hausman test is the most appropriate test to utilize in selecting between the Fixed Effect and the Random Effect. Lastly, the third test is Lagrange Multiplier (LM) (Basuki \& Prawoto, 2016).

In this study, there were classic assumption test and a statistical test in estimating research results. The classic assumption test in panel data included the heteroscedasticity test and multicollinearity test. The statistical test used in this study was the t-test, the F-test, and the R-squared test. Meanwhile, in the selection test, the best model used in the study included the chow test and the Hausman test.

\section{Results}

\subsection{Causality Test}

The heteroscedasticity test was used to identify that there were constant variable variants in the regression model. The results stated that there was no heteroscedasticity problem. Also, multicollinearity test results showed that all variables in the study were free from multicollinearity problems.

\subsection{Model Selection Test}

In selecting the model used in panel data regression analysis, what needs to be carried out was to estimate the Chow Test. Based on the results of the Chow Test, both Cross Section-F and Chi-square values were (0.0000). It indicated that the best method used in panel data regression was the Fixed Effect method. Furthermore, the next test performed was the Hausmant Test. The test showed the probability of a random cross-section of 0.0027 , indicating that the right model used in panel data regression was the fixed effect model.

\subsection{Panel Data Regression Testing Results}

Based on Table 2, partial testing of human development variables on income inequality in Java, Indonesia, had a t-value of 0.005079 and probability value (t-statistic) of $0.0809<0.10$. It indicated that the individual human development index variable had a positive and significant effect on income inequality in the Java island. As for the partial impact of unemployment on income inequality, it had a t-count of 0.015042 and probability value (t-statistic) of $0.0024<0.10$. It indicated that the individual open unemployment rate variable had a positive and significant effect on income inequality in Java. Moreover, the significance level of foreign investment variable influence on income inequality had a calculated value of -0.007537 and a probability value (t-statistic) of $0.1510>0.10$. It indicated that individual foreign investment had a negative, but insignificant effect on income inequality in Java. Furthermore, in terms of the influence of the degree of fiscal decentralization variable on income inequality, it had a t-value of 0.001318 and a probability value (t-statistic) of $0.0265<0.10$. It indicated that the fiscal decentralization degree variable had a positive and significant effect on income inequality in Java. 
Table 2: Fixed Effect Model Estimation Results

\begin{tabular}{|c|c|}
\hline $\begin{array}{c}\text { Dependent Variable: (GINI) } \\
\text { Inequality (Y) }\end{array}$ & Fixed Effect Model \\
\hline A constant $(C)$ & 0.015382 \\
\hline Standard Error & 0.246714 \\
\hline Probability & 0.9507 \\
\hline IPM (X1) & 0.005079 \\
\hline Standard Error & 0.002818 \\
\hline Probability & 0.0809 \\
\hline TPT (X2) & 0.015042 \\
\hline Standard Error & 0.004571 \\
\hline Probability & 0.0024 \\
\hline LOGPMA (X3) & -0.007537 \\
\hline Standard Error & 0.005124 \\
\hline Probability & 0.1510 \\
\hline DDF (X4) & 0.001318 \\
\hline Standard Error & 0.000567 \\
\hline Probability & 0.0265 \\
\hline $\mathbf{R}^{2}$ & 0.745494 \\
\hline $\mathrm{F}_{\text {statistic }}$ & 10.41488 \\
\hline Probability & 0.000000 \\
\hline Durbin-Watson stat & 2.733465 \\
\hline
\end{tabular}

Source: Statistics Indonesia 2012-2018

According to Widarjono (2018), F-test is a test conducted to find out if having more than one independent variable affects the overall dependent variable. Based on the results of the F-test with software analysis tool of E-views 7, the F probability value of $0.000000<0.10$ was obtained. The results of the $\mathrm{F}$ test stated that the independent variables had a significant influence on the dependent variable mutually. The coefficient of determination (R2) measures how far the model's ability in the study in explaining the set of variations of the dependent variable. Regression results employing the fixed effect model method obtained the R-squared value of 0.745494 . It means that $74.5494 \%$ of the independent variables in the research model affected the dependent variable, and the remaining $25.4506 \%$ were influenced by other variables outside the research model.

\section{Discussion}

\subsection{The Effect of Human Development Index on Income Inequality}

The human development index variable had a positive coefficient, which means it influenced a positive income inequality, with a magnitude of the coefficient value of 0.005079 , and with a probability value of 0.0809 . The results of this study contradict the previous hypothesis and also the results of studies discussing income inequality in the Yogyakarta Special Region, by (Hartini, 2017). The economic theory concerning human capital was pioneered by (Becker, 2009; Pyatt, 1966; Schultz, 1992). They stated that people who have a higher level of education as measured by the length of school period would have higher jobs with higher wages than those who have lower levels of education. It is possible that one of the instruments of the Human Development Index, namely the education index, including the average length of schooling, is vital in creating a productive workforce.

According to data from the Central Statistics Agency (BPS), the average length of schooling in Java is relatively high; thus, it can form and create a productive and highly capable workforce that will ultimately increase the per capita income of the community. However, it concerns only in regions with a center of the economy, especially in the central industrial regions or high-income regions that are causing uneven growth and triggering economic disparity. It is supported by research by Arif and Wicaksani (2017), stating that the results of the Human Development Index variable had a positive and significant effect on income inequality in East Java Province in 2011-2015.

\subsection{The Effect of Open Unemployment Rate on Income Inequality}

The open unemployment rate coefficient, with a value of 0.015041 , showed a positive influence between the variable of open unemployment with income inequality. It means that if the open unemployment rate increases by $1 \%$ with the assumption that all variables are fixed, the income inequality will increase by $0.015042 \%$. Besides, the probability value was 0.0024 , which was lower than 0.10 ; thus, it had a positive and significant effect on income inequality in Java in 20122018. The results of this study are in accordance with the hypothesis and previous studies by Rosa and Sovita (2016). In other words, the lower the level of open unemployment is, the higher the income rate to the community will be that can reduce income inequality occurring in Java Island, Indonesia.

\subsection{The Effect of Foreign Investment on Income Inequality}

Foreign investment (PMA) showed a negative sign and was statistically insignificant at a $10 \%$ confidence level. The PMA coefficient had a value of -0.007537 and a probability value of 0.1510 , indicating that foreign investment contributes less to the income inequality of the population on Java island. It is not in accordance with 
the hypothesis, which stated that PMA had a negative and significant effect. It is also different from previous studies conducted by Suanes (2016). This study noted that foreign investment did not significantly influence unequal income distribution in Java. It is due to the foreign investment preference on the capital-intensive tertiary sector rather than the labor-intensive primary and secondary sectors. It was in accordance with the data published by the Capital Investment Coordinating Board. The capital-intensive sector concerns more in utilizing large amounts of capital, both capital for operational activities and business development. In addition, capital-intensive also tend to use sophisticated technology in its activities. This study is in line with the results of previous studies by Pauzi and Budiana (2016), which also stated that foreign investment had no significant effect on income inequality in Bali Province since there were several districts in 2007-2013 that did not obtain an investment invested.

\subsection{The Effect of Fiscal Decentralization Degree on Income Inequality}

The coefficient value of the degree of fiscal decentralization was 0.001318 and had a probability value (t-statistic) of 0.0265 . It indicated that the degree of fiscal decentralization had a positive and significant effect on the error rate of $10 \%$. This study is not in line with the hypothesis, which stated that the degree of fiscal decentralization had a negative and significant effect on inequality. However, it is in accordance with previous studies conducted by Thofan (2019). According to the Indonesian Government of financial regulation No.81/PMK.07/2013, it states that the transfer of funds to the regions is part of state expenditure in the context of implementing fiscal decentralization in the form of balance funds, special autonomy funds, and adjustment funds. Different balance funds for each province lead to an issue. Provinces, which have a high degree of decentralization, or a high level of independence, and also tend to have a low poverty rate in each province, obtain a high balance fund or transfer fund. Conversely, those classified as having a low degree of fiscal decentralization and also classified as a high poverty index actually obtain a low allocation.

\section{Conclusion}

The results of the above research analysis suggest the following conclusion and policy implications:

The test results showed that human development index had a positive and significant effect on income inequality in Java. The human development index is supposed to be a representation of the human quality that can guarantee the equal distribution of income in Java. The government is expected to make a continuous movement to spur the increase in HDI, especially in the index of higher quality education in villages and cities that are expected to produce the best graduates according to the demands of the workforce.

The open unemployment rate had a positive and significant effect on income inequality in Java. The higher level of open unemployment will continue to increase income inequality; thus, the government should increase the spirit of entrepreneurship and make policies that support the growth of the people's economy or the informal sector that can absorb a lot of labor.

The test results of the foreign investment had a negative and insignificant effect on income inequality in Java. The value of foreign investment entering Java can reduce income inequality, but not significantly. It is because the value of the investment is more directed to the capital-intensive sector. The government is expected to be more selective in accepting foreign investments that enter the country, especially in Java, that it should be labor-intensive investments. In addition, the government must equalize locations for foreign investment without reducing good cooperation with these foreign investors.

The degree of fiscal decentralization had a positive and significant effect on income inequality in Java. The degree of fiscal decentralization is the authority of the central government, which is transferred to the regional government. Thus, the regional government must be on the right track in the budget allocation to the productive sector, especially those increasing the income of the small community. Besides, regional government budgets must pay more attention to capital expenditure for labor-intensive production for the lower-class community.

\section{References}

Adelowokan, O. A., Maku, O. E., Babasanya, A. O., \& Adesoye, A. B. (2019). Unemployment, poverty and economic growth in Nigeria. Journal of Economics \& Management, 35, 5-17.

Afonso, A., \& Aubyn, M. S. (2019). Economic growth, public, and private investment returns in 17 OECD economies. Portuguese Economic Journal, 18(1), 47-65. https://doi.org/10.1007/ s10258-018-0143-7

Arif, M., \& Wicaksani, R. A. (2017). Inequality of Income of East Java Province and Its Affecting Factors. Proceeding of the 6th University Research Colloquium: Humanities, Social and Religion Series. September 9, Magelang, Indonesia.

Banister, J., Bloom, D. E., \& Rosenberg, L. (2012). Population aging and economic growth in China in the Chinese economy (pp. 114-149). London: Springer.

Basuki, A. T. (2017). Econometrics and Applications in Economics (Equipped with Eviews 7 Applications). Yogyakarta: Danisa Media.

Basuki, A. T., \& Prawoto, N. (2016). Regression Analysis in Economic \& Business Research (Complete with SPSS \& Eviews Applications). Jakarta: Rajawali Pers. 
Becker, G. S. (2009). Human capital: A theoretical and empirical analysis, with special reference to education. Chicago: University of Chicago press.

Bethencourt, C., \& Perera-Tallo, F. (2020). Human Capital, Economic Growth, and Public Expenditure. Tokyo: Asian Development Bank Institute.

Canavire-Bacarreza, G., Martinez-Vazquez, J., \& Yedgenov, B. (2020). Identifying and disentangling the impact of fiscal decentralization on economic growth. World Development, 127, 104742. https://doi.org/10.1016/j.worlddev.2019.104742

Chulanova, Z. K., Satybaldin, A. A., \& Koshanov, A. K. (2019). Methodology for assessing the state of human capital in the context of innovative development of the economy: A threelevel approach. Journal of Asian Finance, Economics and Business, 6(1), 321-328. http://doi.org/10.13106/jafeb.2019. vol6.no1.321

Chulanova, Z. K., \& Ussenova, S. (2015). Human Capital and Methodic of Determination of Its Cost: A Case of Kazakhstan. Journal of Asian Finance, Economics and Business, 2(2), 1925. https://doi.org/10.13106/jafeb.2015.vol2.no2.19

Crucianu, R., \& Alexandra, P. (2019). The Impact of Unemployment on the Economic Growth in Romania. Ovidius University Annals, Series Economic Sciences, 19(2). 174-179

Fahmi, I. (2018). Introduction to the Indonesian Economy: Theory, Concepts and Reality. Bandung: Alfabeta.

Faridi, M. Z., Mehmood, K. A., Azam, A., \& Taqi, M. (2019). Fiscal decentralization and economic growth in South Asian countries. Pakistan Journal of Commerce and Social Sciences, 13(2), 529-546.

Firmansyah, D., \& Nasih, M. (2019). The influence of local revenue, balancing funds and private investment on economic growth and welfare of communities in East Java Province. Journal of Advanced Research in Dynamical and Control Systems, 11(5), 1241-1251.

Gilbert, N. A., \& François, C. N. O. K. (2020). The Combined Effects of Public and Private Investments on Economic Growth in the CEMAC Zone. Journal of Economic Science Research, 3(1), 1-15. https://doi.org/10.30564/jesr.v3i1.1066

Gu, S., \& Prah, G. J. (2020). The Effect of International Financial Reporting Standards on the Association between Foreign Direct Investment and Economic Growth: Evidence from Selected Countries in Africa. Journal of Accounting, Business and Finance Research, 8(1), 21-29.

Haerani, S., Hakim, W., \& Putra, A. H. P. K. (2020). Structural Model of Developing Human Resources Performance: Empirical Study of Indonesia States Owned Enterprises. Journal of Asian Finance, Economics and Business, 7(3), 211221. https://doi.org/10.13106/jafeb.2020.vol7.no3.211

Han, J.-S., \& Lee, J.-W. (2020). Demographic change, human capital, and economic growth in Korea. Japan and the World Economy, 53, 100984. https://doi.org/10.1016/j.japwor.2019.100984

Hanif, I., Faraz Raza, S. M., Gago-de-Santos, P., \& Abbas, Q. (2019). Fossil fuels, foreign direct investment, and economic growth have triggered $\mathrm{CO} 2$ emissions in emerging Asian economies: Some empirical evidence. Energy, 171, 493-501. https://doi.org/10.1016/j.energy.2019.01.011

Hartini, N. T. (2017). The effect of per capita GRDP, investment and HDI on income inequality between regions in DIY province in 2011-2015. Journal of Education and Economics, 6(6), 530-539. http://journal.student.uny.ac.id/ojs/ojs/index. php/ekonomi/article/view/7227

Hudiyanto, H. (2017). Economic development. Yogyakarta: Lingkar Media.

Le, N. H., Duy, L. V. Q., \& Ngoc, B. H. (2019). Effects of Foreign Direct Investment and Human Capital on Labour Productivity: Evidence from Vietnam. Journal of Asian Finance, Economics and Business, 6(3), 123-130. https://doi.org/10.13106/ jafeb.2019.vol6.no3.123

Li, J., Wang, X., Xu, J., \& Yuan, C. (2020). The role of public pensions in income inequality among elderly households in China 1988-2013. China Economic Review, 61, 101422. https://doi.org/10.1016/j.chieco.2020.101422

Mankiw, N. G. (2018). Introduction to Macro Economics (7th Edition). Jakarta: Salemba Empat.

Molero-Simarro, R. (2017). Inequality in China revisited. The effect of functional distribution of income on urban top incomes, the urban-rural gap and the Gini index, 1978-2015. China Economic Review, 42, 101-117. https://doi.org/10.1016/j. chieco.2016.11.006

Park, Y.-H. (2020). Career Competencies of Human Resource Development Practitioners. Journal of Asian Finance, Economics and Business, 7(4), 259-265. https://doi. org/10.13106/jafeb.2020.vol7.no4.259

Pasara, M. T., \& Garidzirai, R. (2020). Causality Effects among Gross Capital Formation, Unemployment and Economic Growth in South Africa. Economies, 8(2), 1-12. https://doi. org/10.3390/economies8020026

Pauzi, A., \& Budiana, D. N. (2016). Factors that affect directly or indirectly the imbalance of the income distribution of Bali Province. Jurnal Ekonomi Pembangunan, 5(6), 668-691. https:// ojs.unud.ac.id/index.php/eep/article/download/20695/14220

Pradhan, R. P., Arvin, M. B., \& Hall, J. H. (2019). The nexus between economic growth, stock market depth, trade openness, and foreign direct investment: the case of ASEAN countries. The Singapore Economic Review, 64(03), 461-493.

Pratomo, A. M., \& Setyadharma, A. (2020). The Effect of Wages, Economic Growth, and Number of Industries on Unemployment. KnE Social Sciences, 1266-1279. doi: 10.18502/kss.v4i6.6677

Prawoto, N. (2019). Introduction to Macro Economics. Depok: Rajawali Pers.

Pyatt, G. (1966). Human Capital: A Theoretical and Empirical Analysis, with Special Reference to Education. The Economic Journal, 76(303), 635-638.

Rainsford, E., Maloney, W. A., \& Popa, S. A. (2019). The Effect of Unemployment and Low-Quality Work Conditions on Work 
Values: Exploring the Experiences of Young Europeans. The ANNALS of the American Academy of Political and Social Science, 682(1), 172-185.

Schultz, T. (1992). The role of education and human capital in economic development: An empirical assessment (pp. 1-40). Washington DC: Institute for Policy Reform.

Semra, B. (2020). Investigating The Asymmetry Between Economic Growth And Unemployment In Turkey: A Hidden Cointegration Approach. Journal of Economics Finance and Accounting, 7(1), 22-33.

Shi, L., \& Chuliang, L. (2011). How unequal is China? Economic Research Journal, 4, 68-79. http://en.cnki.com.cn/Article_en/ CJFDTotal-JJYJ201104007.htm

Shukla, H. D. (2020). Economic Growth \& Unemployment: An Empirical Analysis of India. Our Heritage, 68(63), 25-29.

Shukla, O. P. (2020). Entrepreneurship Development in India: Role of Foreign Direct Investment and Economic Growth. Journal of Business Management \& Quality Assurance, 3(2), 11-22. doi: http://management.nrjp.co.in/index.php/JBMQA/article/view/407

Srivastava, S., \& Talwar, S. (2020). Decrypting The Dependency Relationship Between The Triad Of Foreign Direct Investment, Economic Growth And Human Development. The Journal of Developing Areas, 54(2), 1-14.

Suanes, M. (2016). Foreign direct investment and income inequality in Latin America: a sectoral analysis. Cepal Review, 118, 45-61. doi: https://doi.org/10.18356/13c68e36-en

Sukirno, S. (2006). Development Economics: Processes, Problems and Policy Basis. Jakarta: Prenada Media Group.

Tambunan, H. (2018). Indonesian economy 1965-2018. Bogor: Ghalia Indonesia.
Thofan, M. (2019). Analysis Of The Effect Of Economic Growth, Ipm, Fiscal Decentralization Of Income Definitions (Case Study In District / City Of East Java Province In 2014-2017). FEB Student Scientific Journal, 8(1), 1-12. https://jimfeb.ub.ac. id/index.php/jimfeb/article/view/6171

Udemba, E. N., Magazzino, C., \& Bekun, F. V. (2020). Modeling the nexus between pollutant emission, energy consumption, foreign direct investment, and economic growth: new insights from China. Environmental Science and Pollution Research, 1-12. https://doi.org/10.1007/s11356-020-08180-x

Udin, U. (2020). Renewable Energy and Human Resource Development: Challenges and Opportunities in Indonesia. International Journal of Energy Economics and Policy, 10(2), 233-237. https://doi.org/10.32479/ijeep.8782

Widarjono, A. (2018). Econometrics: Introduction and Application Accompanied by the Eviews Guide. Yogyakarta: UPP STIM YKPN.

Xie, Y., \& Zhou, X. (2014). Income inequality in today's China. Proceedings of the National Academy of Sciences, 111(19), 6928-6933. https://www.pnas.org/content/111/19/6928.short

$\mathrm{Xu}, \mathrm{Y}$., \& Li, A. (2020). The relationship between innovative human capital and interprovincial economic growth based on panel data model and spatial econometrics. Journal of Computational and Applied Mathematics, 365, 112381. https:// doi.org/10.1016/j.cam.2019.112381

Yang, Z. (2016). Tax reform, fiscal decentralization, and regional economic growth: New evidence from China. Economic Modelling, 59, 520-528. https://doi.org/10.1016/j. econmod.2016.07.020 